\title{
PPM-based Trade Measures to Promote Sustainable Farming Systems? \\ What the EU/EFTA-Mercosur Agreements Can Learn from the EFTA-Indonesian Agreement
}

\author{
Elisabeth Bürgi Bonanomi*, Theresa Tribaldos
}

Table of Contents 1

1 Introduction

2 Diversified farming systems versus specialised, monoculture-based agricultural systems ......................... 5

2.1. Two main categories of farming systems for policy purposes..................................................... 5

2.2. Weak framework conditions for diversified farming systems .................................................. 6

3 Need for an enabling trade framework to promote diversified farming systems ..................................... 7

$4 \quad$ Sustainability chapter versus PPM-related trade measures ….......................................................... 7

4.1. EU/EFTA-Mercosur Agreement: More nuanced sustainability chapter.......................................... 8

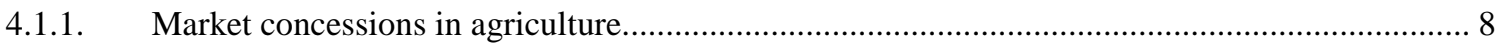

4.1.2. Sustainability chapter to increase diplomatic pressure ..................................................... 8

4.2. EFTA-Indonesia Agreement: Market concessions conditional on sustainability criteria .................. 10

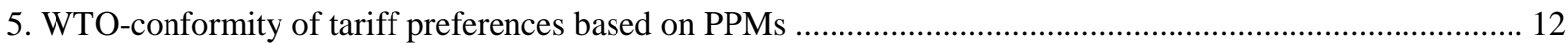

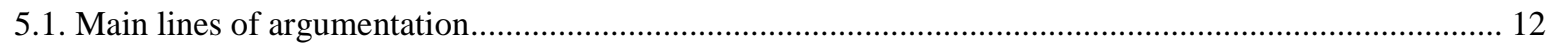

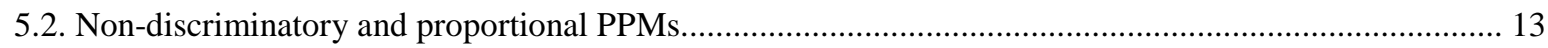

6. The example of Brazil: A missed opportunity in the EU/EFTA-Mercosur Agreement? ............................... 14

6.1. Diversity in Brazil’s landscape and socio-economic disparities: Potential and threats .......................... 14

6.2. Effective policy framework in place, but now weakening ............................................................. 15

6.3. Trade as a lever to promote sustainable development in Mercosur countries and Europe ....................... 16

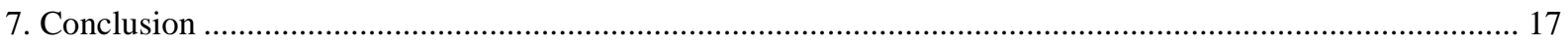

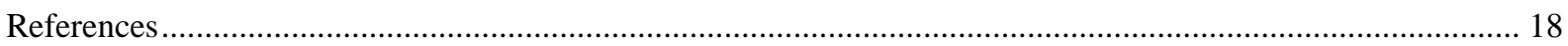

\footnotetext{
* With our warmest thanks to Anu Lannen, editor, and Franziska Orler, research associate, both at the Centre for Development and Environment(CDE), University of Bern, who provided valuable assistance and feedback.
}

Bürgi Bonanomi, Elisabeth

Centre for Development and Environment CDE

Mittelstr. 43, 3012 Bern

email: elisabeth.buergi@cde.unibe.ch
Tribaldos, Theresa

Centre for Development and Environment CDE

Mittelstr. 43, 3012 Bern

email: theresa.tribaldos@cde.unibe.ch 


\begin{abstract}
More sustainable systems of food production are urgently needed. The global community and all involved actors must go beyond focusing narrowly on quantities of food produced; they must simultaneously address interlinked issues of water scarcity, soil fertility loss, agrobiodiversity, climate impacts, equitable land access, labour standards, and other environmental and social issues. The farming systems of the global North and South are highly interdependent, and agricultural trade rules can significantly influence global structures of food production. In view of the increasingly apparent flaws of private sustainability-oriented certification schemes, there is a growing consensus that states can and should use trade-related policy levers to foster more sustainable food production. The present text explores ways of doing so. The approaches taken in the European Free Trade Association (EFTA)-Mercosur Trade Agreement are juxtaposed with those of the EFTA-Indonesian Trade Agreement. The latter agreement structure is argued for, based on its incorporation of tariff differentiation along the lines of process and production methods (PPMs). Accordingly, some thoughts are presented on the conformity of PPM-related trade measures with trade law. The primary concern that emerges regarding PPMs is not whether, but how these can be designed to avoid impinging on fundamental principles of international law, but rather to respect those. Finally, based on a look at the current state of farming systems in Brazil and Argentina, some recommendations are provided as to the optimal design of nuanced, sustainability-oriented trade rules.
\end{abstract}

\title{
1 Introduction
}

The need for more sustainable systems of food production and consumption is an urgent matter of global concern. UN Global Sustainable Development Report (GSDR) 2019, authored by an independent group of scientists appointed by the UN Secretary-General, emphasises that continuing "business as usual" farming systems puts us on a path to disaster. ${ }^{1}$ According to the authors, "upscaling current food production practices to meet the projected food demand of the world's population in 2050 would be completely incompatible with meeting the Paris Agreement as well as many of the Sustainable Development Goals” of the UN 2030 Agenda. ${ }^{2}$ The question is how we can chart a new course in the direction of more sustainable farming systems. Importantly, agricultural trade represents a key policy lever to this end, but much depends on how trade relations are legally shaped.

In order to enable transitions to food sustainability - as envisaged by Sustainable Development Goals (SDGs) 2, on "zero hunger”, and 12, on "responsible consumption and production" - the global community and all involved actors must go beyond focusing narrowly on quantities of food produced. They must simultaneously address interlinked issues of water scarcity, soil fertility loss, climate impacts, food waste, plant pests, and diseases, and more, which are all evolving rapidly in our globalised world. They must also tackle social issues linked to farming systems, such as land concentration, the need for equitable and secure access to land, and labour standards. ${ }^{3}$ More sustainable, agrobiodiverse farming practices need to be encouraged. ${ }^{4}$ Also, smallholder production needs to be strengthened, since small-scale farmers and family farmers

\footnotetext{
${ }^{1}$ Independent Group of Scientists appointed by the Secretary-General, Global Sustainable Development Report (GSDR) (2019), p. xxv (cited: GSDR (2019)). The GSDR 2019 includes summaries data as relating to severe challenges such as biodiversity loss etc.

${ }^{2}$ GSDR (2019), p. 64.

${ }^{3}$ GSDR (2019), pp. 65-66.

${ }^{4}$ For the 'art of doing agriculture', and what it entails, see Bürgi Bonanomi (2015), chapter 7.3.3.; Rist, Bürgi Bonanomi, Giger, Hett, Scharrer, Jacobi, Lannen (2020).
} 
produce a major share of the world's food and are vital to rural poverty-reduction strategies. ${ }^{5}$ According to the GSDR 2019, "to ensure that no one is left behind, much of the increase in food production will have to come from the 750 million smallholder farmers that estimates show will be operating in 2030.” 6

The farming systems of the global North and South are highly interdependent. Food consumption patterns in Europe strongly influence commodity and food production practices not only in European countries, but also in countries of Africa, Asia, and the Americas. Farming system interrelationships shape ecosystems, landscapes, and rural livelihoods at home and abroad. Switzerland's domestic food production, for instance, is very resource intensive and generates significant negative environmental externalities. ${ }^{7}$ Indeed, approximately $73 \%$ of Switzerland's total ecological footprint occurs or originates outside of its national territory. ${ }^{8}$ Consequently, Switzerland must address domestic sustainability issues as well as extraterritorial sustainability issues related to its imports and exports.

The 2030 Agenda - reflecting fundamental principles and objectives enshrined in international treaties on the environment, human rights, and trade - calls upon a broad spectrum of actors with reference to the concept of shared responsibility. Concerning transitions towards more sustainable farming systems, responsibility is attributed to private actors engaged in foodsystem value chains - including input providers, food processors, intermediaries, farmers, citizens, and consumers - but also to public actors at various levels of governance. ${ }^{9}$ The present text deals with the latter; it considers the role of governments in promoting food sustainability by shaping regional and international trade policy.

Trade rules can significantly influence global structures of food production, since trade builds a bridge between geographically distant farming systems. Food production and wider value chains are greatly impacted by the manner in which tariffs are set, subsidies are granted, food standards and labelling schemes are harmonised (or not), intellectual property schemes are aligned (or not), and competition rules are applied to intermediaries (or not). Today, trade in agriculture is governed by the Agreement on Agriculture of the World Trade Organisation (WTO), various other WTO agreements ${ }^{10}$, and a range of regional trade agreements. Also, domestic states unilaterally make use of trade measures - or refrain from their use - when operating within their remaining policy space.

In view of increasingly apparent flaws in private certification schemes and the persistence of severe sustainability problems worldwide, there is a growing consensus that states can and should use trade-related policy levers to foster more sustainable food production. For instance, in a recent public referendum, the citizens of Switzerland approved the addition of Article 104a lit. $d$ to the Swiss Constitution ${ }^{11}$, which obliges the Swiss government to provide for "cross-border trade relations that contribute to the sustainable development of the agriculture

\footnotetext{
${ }^{5}$ Ricciardi, Ramankutty, Mehrabi, Jarvis, Chookolingo (2018); Graeub, Jahi Chappell, Wittman, Ledermann, Bezner Kerr, Gemmill-Herren (2016).

${ }^{6}$ GSDR (2019), p. 65.

${ }^{7}$ For related data, see Bürgi Bonanomi, Jacobi, Scharrer (2018), pp. 27-65. For information concerning Switzerland, see chapter 3.

${ }^{8}$ Bundesamt für Umwelt (2018), p. 39.

${ }^{9}$ The GSDR distinguishes between four levers relevant for transformation: governance, economy and finance, individual and collective action, and science and technology, see GSDR (2019), pp. 67 and 68.

${ }^{10}$ The following WTO agreements are also playing an important role in governing trade in agriculture: WTO General Agreement on Tariffs and Trade of 1947 (GATT); the WTO Agreement on the Application of Sanitary and Phytosanitary Measures of 1994 (SPS Agreement); the WTO Agreement on Technical Barriers to Trade of 1994 (TBT Agreement); the WTO Agreement on Trade-Related Aspects of Intellectual Property Rights of 1994 (TRIPS).

${ }^{11}$ The provision has been in force since 24th September 2017.
} 
and food sector". To date, however, the provision has not been fully realised in policy or practice.

The present text will explore ways of promoting more sustainable farming systems via trade relations. Two categories of farming systems will be outlined, according to which legal distinctions may be made. The possible role of trade in fostering one of the two categories will be reflected upon, and the approaches taken in the European Free Trade Association ${ }^{12}$ (EFTA)Mercosur Agreement will be juxtaposed with those of the EFTA-Indonesian Agreement. The latter agreement structure will be argued for, based on its incorporation of tariff differentiation along the lines of process and production methods (PPMs).

With PPMs, the primary concern that emerges is not whether, but how they can be designed to avoid impinging on fundamental principles of international law - as enshrined in trade, human rights, and environmental law - but rather to respect those. A number of questions arise, such as: How can governments differentiate between sustainable and unsustainable food imports in a fair, responsible and balanced manner that respects the sovereignty of partner countries? How can sustainability distinctions be drawn that are effective, proportionate, context-sensitive, nondiscriminatory, and reliable, by not violating basic principles of trade law and - in the case of wealthy countries - avoid increasing their "protected space" but instead facilitate market access for sustainably produced goods from poorer countries? While the legal analysis in this chapter will necessarily be limited in scope, some thoughts regarding the conformity of PPM-related trade measures with WTO law will be presented. Finally, based on a look at the current state of farming systems in Brazil and Argentina, some recommendations as to the optimal design of nuanced, sustainability-oriented trade rules will be provided.

The emphasis of the present text is not on unilateral trade measures, but rather on trade concessions negotiated in preferential trade agreements (PTAs) ${ }^{13}$. While PTAs should follow basic rules of international trade law, they are typically less scrutinised and less frequently subject to dispute settlement proceedings when compared with domestic measures, since all partners involved have initially agreed to the general terms. This enables PTAs to serve as an experimental framework for testing of new approaches.

Three different interdisciplinary research projects, investigating different aspects of sustainability in farming systems, contributed to the lines of argumentation presented below. The Just Food project explores how just transitions towards sustainable, fair, and healthy food systems can be achieved. ${ }^{14}$ The research project 'Towards Food Sustainability' seeks to assess and compare the sustainability of different types of food systems in Bolivia and Kenya, as well as to explore the influence of different policies on the systems. ${ }^{15}$ The research project "Sustainable Trade Relations for Diversified Food Systems", finally, seeks to explicitly find

\footnotetext{
${ }^{12}$ EFTA countries include Norway, Switzerland, Iceland and Liechtenstein.

${ }^{13}$ Some use the term "Free Trade Agreements FTA". The term PTAs encompasses both bilateral and plurilateral trade agreements; it is more appropriate than FTA since in general, trade is facilitated through those agreements but no free trade area is established.

${ }^{14}$ Transdisciplinary research project 'Just transition: Tackling inequalities on the way to a sustainable, healthy and climate-neutral food system (JUST-FOOD)' of the Strategic Research Council of Finland, financed by the Academy of Finland and led by Dr. Minna Kaljonen, Finnish Environment Institute. The project includes a case study, which is implemented with research partners in Switzerland and Brazil: https://justfood.fi/.

${ }^{15}$ Interdisciplinary research project 'Towards Food Sustainability' of the Swiss Programme for Research on Global Issues for Development (r4d programme), financed by the Swiss National Science Foundation (SNF) and led by Prof. Stephan Rist of the CDE, University of Bern. The project has been implemented in collaboration with research partners in Bolivia, Kenya and https://www.cde.unibe.ch/research/projects/towards_food_sustainability/index_eng.html.
} 
ways of granting tariff preferences for sustainably produced food in a non-discriminatory and balanced way. ${ }^{16}$

\section{Diversified farming systems versus specialised, monoculture-based agricultural systems}

If trade rules are to provide an enabling environment for more sustainable farming systems while disenabling less sustainable ones - lines must be drawn between "the more and the less sustainable", that is, between those farming systems that need more public support/intervention and those that need less. While a great variety of farming systems exist, law-making requires categorisation, as rules and regulations necessarily seek to structure societal processes in a relatively generalised manner. ${ }^{17}$

Accordingly, there is a need for both simplification and legal techniques that enable contextsensitive solutions within general rules. ${ }^{18}$ In the following, two categories will be presented whose contours illustrate useful dividing lines for policy. Subsequently, sections 4 and 5 will make recommendations for context-sensitive solutions along those lines.

\subsection{Two main categories of farming systems for policy purposes}

Debates on food sustainability in the natural sciences, social sciences, and international policy circles reveal a wide range of concepts that embrace those ways of food production that - in this way or the other - are deemed to be more sustainable than others. Prominent concepts include "sustainable agriculture and food value chains", "sustainable intensification", "climate smart agriculture”, "climate resilient agriculture”, “community supported agriculture”, "conservation agriculture”, "agroforestry”, “organic” (or "bio”), "fair trade”, “permaculture”, "agroecology”, "agroforestry", "nutrition sensitive agriculture”, "sustainable land management”, "restoration agriculture", and "ecosystem based approaches". ${ }^{19}$ By promoting these and similar concepts, experts and decision-makers seek to foster agricultural systems that cause fewer negative externalities. Depending on their emphasis, corresponding policy advocates seek to ensure that soil quality, agrobiodiversity, and natural habitats are maintained; that cultural diversity and traditional knowledge are protected; that resources are used efficiently and greenhouse gas emissions are reduced; and/or that farmers' livelihoods are strengthened while local markets are supplied with healthy food at affordable prices.

Dr. Claire Kremen, a professor of applied conservation biology at the University of British Columbia, has sought to identify what constitutes the "core" of that which is considered "more sustainable" in farming system-related debates. Her work has given rise to a means of categorisation that is useful for differentiated law-making. She distinguishes between diversified farming systems and specialised, monoculture-based agricultural systems ${ }^{20}$. In her classification, diversified farming systems are understood as "complex social-ecological systems that enable ecological diversification through the social institutions, practices, and governance processes that collectively manage food production and biodiversity”. ${ }^{21}$ In contrast,

\footnotetext{
${ }^{16}$ Interdisciplinary research project "Sustainable Trade Relations for Diversified Food Systems", financed by the Swiss National Science Foundation (SNF), as part of the National Research Programme 73 on "Sustainable Economy”, and led by Dr. iur. Elisabeth Bürgi Bonanomi of CDE, University of Bern: http://www.nrp73.ch/en/projects/governance/sustainable-trade-relations-for-diversified-food-systems.

${ }^{17}$ Tension between crafting broadly applicable rules and doing justice to the diversity of individual cases has always been inherent in law-making and policymaking; see e.g. Ostrom (2005).

${ }^{18}$ Cf. e.g. Oberlack, Sietz, Bürgi Bonanomi, de Brémond, Dell'Angelo, Eisenack, Ellis, Epstein, Giger, Heinimann, Kimmich, Kok, Manuel-Navarrete, Messerli, Meyfroidt, Václavík, Villamayor-Tomas (2019).

${ }^{19}$ The compilation stems from the workshop 'agroecology works', organised by various Swiss NGOs on 29th August 2019 in Bern.

${ }^{20}$ Kremen, Iles, Bacon (2012).

${ }^{21}$ Kremen, Iles, Bacon (2012), p. 5.
} 
specialised, monoculture-based agricultural systems are those that "simplify ecosystems and utilise highly specialised, technical information with the goal of maximising the profitability of a commodity crop or livestock on a given farm”. ${ }^{22}$

According to Kremen, diversified farming systems tend to "reduce negative environmental externalities and decrease social costs". On the other side, monoculture-based systems tend to maximise production and reduce labour costs. ${ }^{23}$ With respect to environmental externalities, Kremen emphasises that the latter systems have proven "inherently unsustainable [by] mining soils", "polluting waterways, [...] destroying biodiverse habitats, releasing toxins into food chains [...] and contributing to climate warming" 24 . Though it may not be possible to draw a simple dividing line between these two categories of farming system in every case - especially given existing hybrid production forms - they can provide a helpful starting point for governments seeking to adjust their corresponding incentive and disincentive frameworks. ${ }^{25}$

\subsection{Weak framework conditions for diversified farming systems}

Food sustainability scientists have indicated that diversified farming systems and specialised, agro-industrial farming systems could justifiably co-exist ${ }^{26}$. However, they face different challenges from the perspective of sustainability. Concerning specialised, agro-industrial systems, the primary issue is that of incorporating more integral, agrobiodiverse ways of food production into their approach. ${ }^{27}$ Diversified farming systems, by contrast, tend to be marginalised by these dominating agro-industrial systems. Indeed, expansion of large-scale industrialised, monoculture-based systems frequently occurs at the direct expense of more diversified farming systems. ${ }^{28}$. In addition, specialised systems generally benefit from current policy frameworks, while diversified systems typically suffer from insufficiently supportive policy architecture. In addition to lower economies of scale and, in some cases, higher costs of production, diversified systems tend to lack governmental support. Even if countries have innovative legal frameworks in place intended to encourage diversified systems, they tend not to receive the same level of institutional, political, and scientific backing. ${ }^{29}$

Domestic framework conditions primarily need to be adjusted by producer countries themselves. However, they often fail to do so due to their dependency on food commodity exports based on specialised production. ${ }^{30}$ Consumer countries can counteract such dynamics by opening promising new market channels for products stemming from diversified systems

\footnotetext{
${ }^{22}$ Kremen, Iles, Bacon (2012), p. 2.

${ }^{23}$ Kremen, Iles, Bacon (2012), p. 2.

${ }^{24}$ Kremen, Iles, Bacon (2012), p. 1.

${ }^{25}$ Legally, the concept of 'diversified food systems' relates to the idea of 'diversity', which is a key principle in sustainability research. It is opposed to the idea of 'uniformity' as guiding paradigm of the 20th century (see e.g. International Panel of Experts on Sustainable Food systems IPES-Food (2016); High Level Panel of Experts (HLPE) (2019). Reference to diversity has been made, for instance, in Article 6 of the International Seed Treaty (International Treaty on Plant Genetic Resources for Food and Agriculture [ITPGRFA] of 2001), which requires member states to pursue agricultural policies that promote “diverse farming systems”. Bürgi Bonanomi (2015), pp. 284-288.

${ }^{26}$ Eyhorn, Muller, Reganold, Frison, Herren, Luttikholt, Mueller, Sanders, Scialabba, Seufert, Smith (2019).

${ }^{27}$ Eyhorn, Muller, Reganold, Frison, Herren, Luttikholt, Mueller, Sanders, Scialabba, Seufert, Smith (2019).

${ }^{28}$ Kremen, Iles, Bacon (2012); Messerli, Giger, Dwyer, Breu, Eckert (2014), pp. 449-459.

${ }^{29}$ See e.g. for Kenya: Kiriti Nganga, Mugo, Bürgi, Kiteme (2018). The work is i.a. based on evidence from the R4D project “Towards Food Sustainability” in which the authors have participated. The R4D research in Bolivia, Kenya and further contexts has shown how those farming systems which are particularly relevant from a sustainability perspective are often too weak to evolve, given that they compete with systems producing more negative externalities. For related publications, see

https://www.cde.unibe.ch/research/projects/towards_food_sustainability/index_eng.html.

${ }^{30}$ De Schutter (2009a).
} 
and leveraging them for commercial purposes. ${ }^{31}$ It is here that trade - and the way it is shaped - can play an important enabling role.

\section{Need for an enabling trade framework to promote diversified farming systems}

In order to ensure that diversified farming systems gain momentum and do not get displaced by specialised, monoculture-based systems, framework conditions need to be adjusted. In a governance system that would internalise external costs (e.g. environmental harms), unsustainable patterns of farming would be costlier or even illegal. In practice, this does not (yet) happen. However, a sustainability-oriented trade framework could be used as a lever to address this. If products stemming from diversified farming systems could benefit from easier access to markets of high purchasing power, more investment for such systems could be secured. ${ }^{32}$ Thereby, for farmers, access to both local as well as international markets is relevant and eventually complementary. In UNCTAD's Trade and Environment Review 2013, the authors put it as follows: "More regionalised/localised food production networks should be encouraged by trade rules, without excluding the supplementary role trade will have to play". 33 This gives rise to the following question: How can trade measures be redesigned to create an enabling environment for the promotion and re-emergence of diversified farming systems? The current trade system, by not differentiating between production types, incentivises the cheapest or most subsidised types of production, not those that perform most sustainably. To enable sustainable farming systems, corresponding incentives should be set differently.

When evaluating whether a unilateral trade measure resp. a trade agreement effectively creates an enabling environment for food sustainability, assessments must go further than the "legal letter". Instead, effective impacts of any new rule must be considered, including economic dynamics that may be reinforced. While one trade measure alone may not sufficiently strengthen diversified farming systems, it may do so when included as one element in a wider, more comprehensive policy package. ${ }^{34}$

\section{Sustainability chapter versus PPM-related trade measures}

Debates over "trade and food sustainability" mainly revolve around whether to pursue any of the following policies in trade regulation: increasing discipline of agricultural subsidies; strengthening transparency in food value chains by means of voluntary or compulsory labelling requirements; introducing more nuanced sustainability chapters in trade agreements; limiting protection of intellectual property as related to agricultural inputs; control the use of standards by intermediaries in order to ensure that inclusive frameworks are in place; strengthening competition rules to ensure fair market prices; promoting recognition of equivalence of food and production standards; or introducing tariff differentiation based on PPMs.

The present text cannot address all of these policy aspects but will focus on two of them. It will compare and contrast two distinct regulatory approaches - namely, (1) introduction of a more nuanced sustainability chapter, as included in the EU-Mercosur Trade Agreement as well as the EFTA-Mercosur Free Trade Agreement (henceforth: the EU/EFTA-Mercosur Agreements), versus (2) PPM-related trade measures, as included in the EFTA-Indonesian Comprehensive Economic Partnership Agreement (CEPA) of 2018. While the latter approach - here

\footnotetext{
${ }^{31}$ Food and Agriculture Organization of the United Nations (FAO), Institut national de la recherche agronomique (INRA) (2016); Tschopp, Bieri, Rist (2018), pp. 402-427.

${ }^{32}$ See e.g. Bürgi Bonanomi (2011), pp. 68-88.

${ }^{33}$ United Nations Conference on Trade and Development (UNCTAD) (2013), chapter 5.

${ }^{34}$ Theory on sustainability impact assessments (SIA) of trade agreements begins with the assumption that trade agreements should be understood as but one element of a broader policy picture: "Systemic thinking requires that the dynamics the agreement might trigger be explored in the context of the overall trade policy in which the agreement is embedded” (Bürgi Bonanomi (2017), pp. 481-503.). Policy impacts may be anticipated based on detailed knowledge of the contexts involved.
} 
introduction of PPM-related trade measures in the case of palm oil - promises to be more effective, some thoughts will be given as to their compatibility with WTO law.

\subsection{EU/EFTA-Mercosur Agreement: More nuanced sustainability chapter}

\subsubsection{Market concessions in agriculture}

The following section refers to the documents available at the time of writing: the final draft text of the EU-Mercosur Trade Agreement, the concluding note as regards the EFTA-Mercosur Free Trade Agreement ${ }^{35}$, and the final text of the CEPA. ${ }^{36}$

Particularly relevant - from a food sustainability perspective - are the market concessions for agricultural products which are granted once the Agreement is finally ratified. As regards EUMercosur trade relations, on 93\% of tariff lines, duties for EU agri-food exports to Mercosur countries will be eliminated gradually. At the same time, the EU will liberalise $82 \%$ of agricultural imports, and will offer limited tariff-rate quotas for sensitive products such as beef, poultry, pork sugar, ethanol, rice, honey, and sweetcorn. Finally, reciprocal tariff-rate quotas for cheese and milk will be implemented. The EU states approvingly that the agreement will offer EU industries "cheaper high-quality raw material by reducing or eliminating duties that Mercosur currently imposes on exports to the EU of products such as soybean products (feed for EU livestock)." 37

The EFTA-Mercosur Free Trade Agreement includes similar market concessions. According to the EFTA secretariat, "the Agreement provides for meaningful tariff concessions on both basic and processed agricultural products.” Export from the EFTA to Mercosur countries will be facilitated for cheese, roasted coffee, and processed sugar products such as chocolate, while at the same time, Mercosur products will benefit from more generous import quotas for beef, poultry, pork, soy, wheat, and oil. ${ }^{38}$

\subsubsection{Sustainability chapter to increase diplomatic pressure}

Aware that the production of meat, soy, and other agricultural products, is associated with serious sustainability concerns (see Section 5), the negotiators were under pressure to take account thereof. As a result, they opted to indirectly link market concessions to sustainability criteria by means of a sustainability chapter featuring more nuanced language than in the past. In the case of the EU-Mercosur agreement, a new institutional architecture for implementation of the chapter has been added.

In the relevant chapters on "trade and sustainable development", the trading partners commit to taking environmental and human rights standards seriously, in particular those to which they are already bound based on their prior adoption of international treaties. While each party is permitted to define its own level of social and environmental protection, a "race to the bottom" between the partner countries shall ostensibly be avoided by adhering to minimum standards. ${ }^{39}$

As previous sustainability chapters in trade agreements have been criticised for unspecific wording or lack of implementation ${ }^{40}$, the new sustainability chapter of the EU-Mercosur agreement includes quite specific, nuanced wording. According to its Article 6 on "Trade and Climate Change", for instance, each party to the agreement shall "promote the positive contribution of trade to a pathway towards low greenhouse gas emissions and climate-resilient

\footnotetext{
${ }^{35}$ European Free Trade Association Secretariat (EFTA) (2019) (cited: EFTA (2019)). Final draft of the Agreement not yet published at the time of writing.

${ }^{36}$ Signed at the 16th December 2018, but not yet ratified at the time of writing.

${ }^{37}$ European Union EU (2019), p. 3.

${ }^{38}$ See EFTA (2019).

${ }^{39}$ By maintaining the partners' "right to regulate" and "right to define level of protection" in those areas.

${ }^{40}$ See e.g. Swiss Federal Council (2017), for sustainability chapters as included in EFTA-Agreements.
} 
development [...] that does not threaten food production". According to Article 7 on "Trade and Biodiversity", each party shall "encourage trade in natural resource-based products obtained through a sustainable use of biological resources or which contribute to the conservation of biodiversity". And according to Article 8 on "Trade and Sustainable Management of Forests", the parties shall "encourage trade in products from sustainably managed forests harvested in accordance with the law of the country of harvest", "promote [...] the inclusion of forest-based local communities and indigenous peoples in sustainable supply chains of timber and non-timber forest products", and "combat illegal logging and related trade". The EFTA-Mercosur Free Trade Agreement includes similar provisions, while a specific article on "trade and sustainable agriculture and farming systems" stipulates the commitment of the parties "to promote sustainable agriculture and associated trade and conduct a dialogue to address related issues". 41

Technically, the sustainability chapter is legally binding. However, in the case of violations, access to dispute settlement mechanisms has regularly been excluded in EU and EFTA agreements. ${ }^{42}$ As a result, in case of violations of the sustainability chapter, trade concessions will not be suspended. This architecture reflects the view that a trade-related dispute settlement body is not suited to adjudicate on implementation of environmental and human rights standards in partner countries, since the commitments laid down in the sustainability chapter concern each country as a whole. In cases of severe disregard of the sustainability chapter, partner countries - instead of suspending trade concessions - are called for consultation to ensure its implementation.

In response to past accusations of little relevance of this approach, a new institutional architecture has been included in recent agreements, including the EU-Mercosur Agreement. Recourse to dispute settlement remains excluded in case of violations of the chapter (Article 15). A party may, however, request consultations with the other party "regarding the interpretation or application of this Chapter" (Article 16). If no resolution can be reached, "a Party may request the establishment of a Panel of Experts to examine the matter" (Article 17). The panel of experts may issue recommendations which the parties shall discuss (Article 17). This institutional structure could serve to increase diplomatic pressure. However, no further sanctions are envisaged. As regards the EFTA-Mercosur agreement, the form of the "consultation architecture" is not yet known.

From a sustainability perspective, the EU, EFTA, and Mercosur countries deserve credit for having introduced a sustainability chapter into their trade agreements. In theory, the sustainability chapter restricts all partner countries to trading products that have been produced in compliance with the stated criteria, enabling effective promotion of diversified farming systems. However, due to the lack of sanctions or the possibility to suspend trade concessions in case of violations, the effectiveness of the chapter will remain limited: There is a risk of waning interest in debating sustainability issues after the agreement enters into force. Further, consultations cannot be requested by interested stakeholders, but rather only by parties to the agreement. The latter may be reluctant to request compliance with the sustainability chapter as a result of issues of political economy. It remains to be seen whether the new institutional setup in the EU-Mercosur Agreement, requiring creation of a panel of experts, will reinforce the effectiveness of the chapter. As a particularly powerful actor, the EU could have more leeway in this regard than the EFTA or the Mercosur countries. Significantly, Mercosur countries could equally reproach the EU and EFTA countries for not producing in a sustainable way.

\footnotetext{
${ }^{41}$ See EFTA (2019).

${ }^{42}$ Cf. Bartels (2014).
} 
Finally, the effectiveness of the sustainability chapter will remain limited because "human rights and sustainability impacts flow from all parts of the agreement". ${ }^{43}$ The trade concessions granted in the agreement, explicit commitments to strengthen intellectual property (IP) regimes - but also issues Parties missed to address - can directly impact the sustainability trajectory of each country. In order to ensure sustainable outcomes, it is often more relevant how related provisions are shaped than how the sustainability chapter is formulated.

Taken together, sustainability chapters can serve as an important entry point not only for diplomatic discussions, but also for technical cooperation, ideally in combination with privatesector initiatives. However, more targeted mechanisms are available to promote diversified farming systems. The EFTA-Indonesian agreement, for instance, has made market concessions in palm oil trade directly conditional on sustainability criteria, as shall be discussed in the next section.

\subsection{EFTA-Indonesia Agreement: Market concessions conditional on sustainability criteria}

One particularly direct trade mechanism for promotion of diversified farming systems is that of tariff differentiation (or equivalent measures) based on the quality of PPMs. According to this approach, a partner country may - upon agreement with its negotiating partner(s) - introduce preferential tariffs for sustainably produced food, reserve (a share of) import quotas for them, or require domestic food processors to source from them. Tariff differentiation has been chosen in the CEPA to support more sustainable ways of producing palm oil in Indonesia.

The CEPA includes in its Annex V tariff concessions granted by the EFTA countries to Indonesia. ${ }^{44}$ As stated in the "Schedule on tariff commitments on goods, commitments of Switzerland", raw palm oil of a certain category A (no feed) may benefit from an import quota ranging between 1,000 and 1,250 tons as well as a tariff reduction ranging between $30 \%$ and $53 \%$. The quota for palm oil of a certain category B is a bit larger, and there are specific concessions for oil of specific quality. ${ }^{45}$ Furthermore and significantly, the annex includes the following specification in small print:

*=Products of HS heading 15.11 und 15.13 imported into Switzerland under this Agreement shall meet the sustainability objectives as set out in Article 8.10 (Sustainable Management of the Vegetable Oils Sector and Associated Trade) of the Agreement. ${ }^{46}$

This refers to Article 8.10. of the sustainability chapter of the CEPA, which explicitly states under paragraph 2 that the parties must:

effectively apply laws, policies and practices aiming at protecting primary forests, peatlands, and related ecosystems, halting deforestation, peat drainage and fire clearing in land preparation, reducing air and water pollution, and respecting rights of local and indigenous communities and workers; [...]

and further that the parties must

(e) ensure that vegetable oils and their derivatives traded between the Parties are produced in accordance with the sustainability objectives referred to in subparagraph (a) ${ }^{47}$

\footnotetext{
${ }^{43}$ Dommen (2020), p. 39.

${ }^{44}$ The text of the agreement can be found here: https://www.efta.int/free-trade/Free-Trade-Agreement/indonesia.

${ }^{45}$ For more detailed explanations regarding those commitments, see Bürgi Bonanomi (2019).

${ }^{46}$ Harmonised system (HS) heading 15.11 refers to palm oil, HS 15.13 to oil from coconut, palm kernel and babassu.

${ }^{47} \mathrm{An}$ identic add-on is included in the versions relevant for the other EFTA countries Norway, Iceland and Liechtenstein.
} 
As a consequence, palm oil imported from Indonesia to the EFTA countries must be produced in a sustainable way that ensures Indonesian primary forests and peatlands remain protected; ensures deforestation, peat drainage, and fire clearing are halted; ensures air and water pollution are reduced; and ensures the rights of both local and indigenous communities as well as workers are respected. The provision refers to existing laws and policies of Indonesia, implicitly suggesting that requisite laws are in place but that their implementation needs to be strengthened. ${ }^{48}$

In addition, to ensure traceability along the value chain, further requirements have been included, such as that the respective palm oil must be transported "in tanks of not more than 22 tons". ${ }^{49}$ Of significance in this regard is the Cooperation Chapter 9 of the CEPA, according to which EFTA countries agree to intensify cooperation, inter alia to assist Indonesia in establishing inclusive and sustainable production and value chains in the palm oil sector. ${ }^{50}$ Cooperation consists in knowledge transfer and financial support. However, the desired extent of such cooperation is not explicitly quantified.

Hence, in the face of harsh criticism in the EFTA countries concerning "unsustainable" Indonesian palm oil production ${ }^{51}$, the partner countries to the CEPA have opted to go a step further and directly link sustainability criteria to trade concessions. Actual implementation will reveal whether such mechanisms can truly foster sustainable and inclusive value chains in the palm oil sector. Much will depend on the returns that can be obtained for sustainable palm oil when benefitting from (limited) tariff reduction, and on the control mechanism that is put in place. Importing countries will need to further concretise the criteria set out in Article 8.10.2 of the CEPA and further specify key elements of a sustainable and inclusive palm oil production system, such as equitable inclusion of small-scale farmers. They could then maintain a positive list of credible sustainability certification schemes that cover all the cited aspects. Certified products would then benefit from preferential tariffs as long as no serious doubts arise as to the rigour of certification.

Research on palm oil production in Indonesia shows that existing certification schemes come with serious deficiencies, as does actual palm oil production itself. ${ }^{52}$ Tariff incentives alone may not be sufficient to improve the quality of certification schemes or actual production systems. Instead, strong programmes promoting transformation of current palm oil production, equipped with the necessary financial and technical support, may be needed.

To conclude, if the obligation to ensure compliance with sustainability criteria is solely left to private palm oil importers, these companies may find it too risky and shift their import business to other producer countries. If, however, tariff incentives to produce sustainably are combined with effective financial support of importing countries, the innovative approach is much more likely to succeed since regarded as equitable and fair by involved stakeholders.

\footnotetext{
${ }^{48}$ See Bürgi Bonanomi (2019).

${ }^{49}$ Annex II, lit. i of the CEPA.

${ }^{50}$ Article 9.2 of the CEPA reads as follows: "Cooperation and capacity building shall cover sectors affected by the process of liberalisation and restructuring of the Indonesian economy as well as sectors with the potential to benefit from this Agreement.”

${ }^{51}$ For academic literature concerning the challenges of palm oil production in Indonesia, see e.g. Znoj (2016); Colchester and Chao (2013); Murray Li (2017a); Murray Li (2014); McCarthy (2010); Murray Li (2017b); Beckert, Dittrich, Adiwibowo (2014); Manoli, Meijide, Huth, Knohl, Kosugi, Burlando, Ghazoul, Fatichi (2018). ${ }^{52}$ See e.g. Znoj (2016); Colchester and Chao (2013); Murray Li (2017a); Murray Li (2014); McCarthy (2010); Murray Li (2017b); Beckert, Dittrich, Adiwibowo (2014); Manoli, Meijide, Huth, Knohl, Kosugi, Burlando, Ghazoul, Fatichi (2018).
} 


\section{WTO-conformity of tariff preferences based on PPMs}

Overall, tariff incentives related to product differentiation - based on inclusive PPMs and combined with financial support - appear promising to promote more inclusive and diversified agricultural systems and incentivise respective transformation processes. Though such approaches may be required from a human rights and environmental law perspective, the question arises as to whether they are in compliance with WTO law. While bilateral and plurilateral trade agreements tend to be less scrutinised, they should still strive to follow the basic rules of international trade law to which most bilateral trade agreements refer explicitly and implicitly. The basic principles of international trade law are enshrined in various WTO agreements. To a limited extent, they provide some scope for sustainability related incentives.

\subsection{Main lines of argumentation}

A range of WTO case law deals with sustainability-oriented import barriers and quotas, conditioning of preference systems, sanitary and phytosanitary standards related to sustainability concerns, and labelling rules. ${ }^{53}$ Though WTO compatibility is best examined in connection with concrete measures subject to challenge, there are several general considerations relevant to PPM-related trade measures that can be derived from current general jurisprudence. ${ }^{54}$ At the centre of debate is, on the one hand, the question of how to interpret the most-favoured nation (MFN) clause and the national treatment (NT) clause as codified by Article I and Article III GATT (especially in connection with Article XI GATT on the regulation of import quotas). Should a product be considered a "like product" when it has similar characteristics to another product, but has been produced in a different way? According to current WTO jurisprudence - based above all on Border Tax Adjustment criteria ${ }^{55}$ - one may assume that a conventionally produced banana and a banana stemming from a diversified farming system will be treated as "like" by the dispute settlement body of the WTO, thus excluding differential tariff treatment. Much depends, however, on how interpretation of the criteria of "consumer tastes and habits" evolves in the coming years, that is, whether consumers increasingly (desire to) distinguish between sustainably produced goods and non-sustainably produced goods such that they are not considered interchangeable. ${ }^{56}$

Since interpretation of the above-mentioned provisions has been rather restrictive so far, the General Exceptions formulated in Article XX GATT assume a further key role in the current jurisprudence. These exceptions allow for suspension of trade concessions for the protection of certain public interests - especially environmental interests, but also specific social goods, if

\footnotetext{
${ }^{53}$ The following WTO cases are particularly worthy of note: US-Restrictions on Imports of Tuna II (1994); USMeasures Concerning the Importation, Marketing and Sale of Tuna and Tuna Products (Tuna III, 2012); USImport Prohibition of Certain Shrimps and Shrimp Products (Shrimps Case, 1998); EC-Measures Concerning Meat and Meat Products (Hormones Case, 1998); EC-Conditions for the Granting of Tariff Preferences to Developing Countries (GSP-Case, 2004); US-Measures Affecting the Cross Border Supply of Gambling and Betting Services (Gambling Case, 2005); EC-Measures Affecting the Approval and Marketing of Biotech Products (GMO-Case, 2006); Brazil-Measures Affecting the Imports of Retreaded Tyres (2007); China-Measures Related to the Exportation of Various Raw Materials (2012); and EC-Measures Prohibiting the Importation and Marketing of Seal Products (Seals Case, 2014). The full cases may be found at https://www.wto.org/english/tratop_e/dispu_e/dispu_status_e.html or http://www.worldtradelaw.net/. For explanations and the relevance of the cases for sustainability concerns, refer to De Schutter (2015) or to Bürgi Bonanomi (2015), chapter 3. For a sustainability related analysis of the seal case, refer to Cottier (2018), pp. 6992.

${ }^{54} \mathrm{PPMs}$ in trade and related tariff differentation have been debated in literature on climate protection and trade. See e.g. Holzer (2014); Cottier, Nortova, Shingal (2014).

${ }^{55}$ According to border tax adjustment criteria as developed by the WTO jurisprudence, products must be treated as "like" if they come with the same physical characteristics, if consumers' tastes and habits imply that the products are substitutable, if the products' end-uses in a given market are identic and if tariff classification is the same. See Cottier, Oesch, (2005), p. 403.

${ }^{56}$ See De Schutter (2015), pp. 48 ff. See also Howse (2012), p. 446.
} 
they are "connected" in some way to the country providing the trade measure. In several cases, the existence of justifiable public interests in accordance with Article XX GATT has been recognised, showing there is some scope for sustainability-oriented trade measures. The main challenge today lies in the conditions of the chapeau of Article XX GATT, which refers to principles of non-discrimination and proportionality. As Cottier states, many PPMs imposed by countries have so far "failed to pass these tests and had to go back to the drawing board, however without being excluded in principle" ${ }^{57}$. States that have introduced corresponding measures have lost in most cases, with their actions foundering on the non-discrimination clause. The arbitrators argued that the controversial measures served to favour domestic production, in a protectionist manner, since foreign suppliers could not implement them as easily as domestic suppliers. ${ }^{58}$

However, if designed in a non-discriminatory and proportional way, PPMs could very well pass WTO scrutiny. It is also important to note that WTO jurisprudence is dynamic and continues to evolve. In view of the global sustainable development agenda, it is becoming increasingly supportive of measures that seek to internalise social and environmental concerns, and is gradually shifting from a trade-liberalisation paradigm to a more complex trade-regulation paradigm that embraces trade and stabilisation concerns. ${ }^{59}$

\subsection{Non-discriminatory and proportional PPMs}

In view of the principles of non-discrimination and proportionality enshrined in WTO law, PPM-based tariff preferences have the best chance of withstanding WTO scrutiny when the following aspects are kept in mind. First, sustainability criteria should be flexibly tailored to cover various socio-environmental contexts and production conditions, building in particular on promising transformation processes already underway on the ground. ${ }^{60}$ Accordingly, a requirement to comply with the domestic standards of the importing country - for instance mandating foreign production according to Swiss domestic organic ("bio") standards - would not be acceptable. Second, sustainability criteria as required by external suppliers should be equally applied to domestic actors in order for the policy measure to be consistent. Also, the measure must be designed in a proportional way, that is, no more interventional than necessary to reach the targeted objective. Finally, PPM-based tariff preferences will follow the spirit of trade law if - through the preferences - market access for sustainably produced products is effectively facilitated. This may require implementation of a package of policy measures, including recognition of local standards and procedures of foreign contexts as being equivalent to domestic ones, as well as the warranting of adequate financial and technical support. ${ }^{61}$

New practices as integrated in the CEPA bring the PPM issue back to the forefront of the debate. In general, the trade landscape is increasingly shaped by PPM-based trade measures. This can be seen, for instance, in domestic timber, fisheries, and biofuel regulation. ${ }^{62}$ At the same time, there has been an evident shift in the public discourse as regards the PPM issue. Today, the

\footnotetext{
${ }^{57}$ Cottier (2015), p. 4.

${ }^{58}$ The 1998 shrimp case is generally referred to as a key precedent. It was decided that a country seeking to introduce a trade-hindering measure based on public interest grounds must demonstrate that it is working towards a concerted approach at the international level. At the same time, the measures must be designed such that trading partners could also implement them; see: Bürgi Bonanomi (2015), pp. $111 \mathrm{ff}$. The jurisprudence on standards and technical rules such as labels directly or indirectly supported by the government similarly requires - based on the SPS and TBT agreements - that these be designed in a consistent and non-discriminatory manner. The SPS Agreement further requires that the standards withstand scientific scrutiny (which led the EU to lose, for example, in the hormone case). For a thorough analysis of the current legal situation and corresponding jurisprudence, refer to De Schutter (2015).

${ }^{59}$ Musselli (2017).

${ }^{60}$ Bürgi Bonanomi, Jacobi, Scharrer (2018).

${ }^{61}$ Cottier (2015), pp. 6-7.

${ }^{62}$ Solar, Bürgi Bonanomi (forthcoming, 2021) PPMs in European Trade Practice. Comparative Legal Analysis.
} 
argument is less that PPMs are not compliant with trade law, but rather that much depends on their design. ${ }^{63}$ The question is, hence, not whether, but how the standard setting can be made transparent, inclusive, non-discriminatory, and consistent vis-à-vis domestic actors, without imposing unfair costs on the most vulnerable - namely, small producers, developing countries, and poor consumers. Finally, strengthening the economic competitiveness of sustainably produced food and making it affordable to low- and middle-income consumers presents another important economic rationale for involving not only private actors, but also state actors.

\section{The example of Brazil: A missed opportunity in the EU/EFTA-Mercosur Agreement?}

In the previous sections, it has been argued that trade concessions based on PPMs, if designed in a non-discriminatory and inclusive way, have the potential to effectively promote diversified farming systems. In order to get their design right, in concrete trade negotiations, recourse to context-based knowledge is indispensable.

With respect to the EU/EFTA-Mercosur agreements, all the partner countries involved could have deliberately tabled sustainability-related arguments concerning food systems. Not only European, but also Mercosur countries could have asked the partner countries to promote diversified farming systems through the established trade relations. Also in most European countries, a rather ambivalent set of agricultural policies remains in place: Sustainabilityoriented support measures have been introduced alongside measures promoting intensification of agricultural production - with the latter often generating negative environmental and social effects. ${ }^{64}$ Nevertheless, in the relevant trade negotiations, it has mainly been the European countries confronting Mercosur countries with sustainability concerns rather than the other way round. Accordingly, in the following, some current patterns of farming systems in Brazil and Argentina will be presented that enable reflection on the optimal design of product differentiation.

\subsection{Diversity in Brazil's landscape and socio-economic disparities: Potential and threats}

Brazil is an interesting case when investigating the potential for co-existence of diversified and specialised agro-industrial farming systems. Brazil is the fifth largest country in the world, encompassing an area of 236 million hectares of which almost 30\% is under agricultural production. ${ }^{65}$ Its local biomes range from tropical rainforest to semi-arid savannah, presenting a wealth of opportunities for different forms of agricultural production. Since the 1960s, largescale, agricultural production has massively expanded in Brazil, bringing with it severe environmental and social consequences. ${ }^{66}$

Deforestation of biomes rich in biodiversity is a well-known problem associated with expansion of agro-industrial production. While the Amazonian tropical rainforest in Brazil is not an appropriate biome for intensive agricultural production, national and international market opportunities for commodities such as soy and beef have nonetheless driven growth of intensive production in these areas and accordingly deforestation ${ }^{67}$. Existing state protection schemes of the Amazon and other natural landscapes have proven weak and incapable of hindering

\footnotetext{
${ }^{63}$ This was the agreed narrative at the World Trade Forum (WTF) 2019, organised by the World Trade Institute WTI in Bern, Switzerland. For a prominent reference in the media, see e.g. Vonplon D, Freihandel und Nachhaltigkeit passen zusammen. Neue Zürcher Zeitung NZZ, 17. Oktober 2019.

${ }^{64}$ For Switzerland, for instance, compare with Rist, Bürgi Bonanomi, Giger, Hett, Scharrer, Jacobi, Lannen (2020). For example, cities like Nuremberg or Geneva (see section 1.3), or even entire countries, like Brazil see Inguaggiato (2014), have committed to purchasing mainly 'sustainably produced food' when supplying hospitals or schools.

${ }^{65}$ FAOSTAT (access to food and agriculture data of the Food and Agriculture Organization of the United Nations (FAO)) (2020) Data for the year 2017. http://www.fao.org/faostat/en/\#data, (last accessed 15 January 2020).

${ }^{66}$ Graesser, Ramankutty, Coomes (2018).

${ }^{67}$ Bowman, Soares-Filho Merry, Nepstad, Rodrigues, Almeida (2012).
} 
deforestation in practice. ${ }^{68}$ After declining for a time, deforestation rates in the Amazon have been on the rise again since 2014. ${ }^{69}$ The Cerrado, a Brazil-specific biome adjacent to the Amazon, can be described as something between tropical rainforest and savannah. Though it has received less media attention, the Cerrado is home to other key agricultural frontiers associated with severe pressures of deforestation. ${ }^{70}$

Both biomes, the Amazon and the Cerrado, are rich in biodiversity and could provide a good basis for inclusive, small-scale, agrobiodiversity-based forms of agricultural production. They are particularly suited to ways of cultivation that sustain intact nutrient cycles, protect soils and water resources by avoiding or limiting use of chemical inputs, and support existing biodiversity by applying agricultural practices that are adapted to local conditions. Such forms of agricultural production can provide livelihoods for rural communities and support healthy, diverse diets ${ }^{71}$. In economic terms, they have the potential to create jobs in production and processing of local agricultural goods, provided that profitable markets can be established for staple food and processed products resulting from such food systems.

At present, however, local expansion of agro-industrial frontiers seriously endangers biodiversity in both the Amazon and the Cerrado, also undermining the potentials described for local communities. Research evidence shows that this agro-industrial expansion is often associated with displacement of communities, sometimes including severe violations of human rights. ${ }^{72}$ Under these conditions, co-existence of small-scale, diversified agricultural production and large-scale, agro-industrial production has proven to be too challenging.

The dynamics are exacerbated by socio-economic disparities. Brazil is characterised by extreme income and wealth inequality ${ }^{73}$ as well as literacy problems among rural populations. Though inequality fell somewhat in Brazil between 2001 and 2014, owing to a combination of economic growth and social reforms, ${ }^{74}$ the country still ranks among the most unequal in the world ${ }^{75}$ in terms of income and wealth distribution. Inequality is also high in the states currently experiencing the greatest expansion of agricultural frontiers, including Amazonas, Para, Maranhão, Tocantins, Piaui, and Bahia. Among other issues, high illiteracy rates ${ }^{76}$ complicate efforts to defend people against human rights violations and displacement in Brazil's poorest states.

\subsection{Effective policy framework in place, but now weakening}

In order to cope with such challenges, an elaborate policy framework was developed in recent decades aimed both at reducing poverty and inequality and at supporting rural farming families. Based on the "zero hunger" strategy, the government of the Partido dos Trabalhadores (PT) introduced a widely praised programme in 2002 seeking to fight hunger, ensure social welfare, and stimulate jobs and income growth through well targeted economic measures. Introduced in a period of national economic growth, the strategy successfully lifted millions of Brazilians out of poverty. ${ }^{77}$ Two of the most-influential parts of the strategy have been the family-farming

\footnotetext{
${ }^{68}$ Graesser, Ramankutty, Coomes (2018).

${ }^{69}$ Escobar (2019).

${ }^{70}$ Graesser, Ramankutty, Coomes (2018); Moffette and Gibbs (2018), p. 21.

${ }^{71}$ Chappell and LaValle (2011).

${ }^{72}$ Celentano, Rousseau, Muniz, van Deursen Varga, Martinez, Carneiro, Miranda, Barros, Freitas, da Silva Narvaes, Adami, Rodrigues Gomes, Rodrigues, Martins (2017), p. 694.

${ }^{73}$ International Social Science Council (ISSC), Institute of Development Studies (IDS), United Nations Educational, Scientific and Cultural Organization (UNESCO) (2016).

${ }^{74}$ Góes and Karpowicz (2017), p. 4.

${ }^{75}$ The World Bank (2020) World Development Indicators. http://datatopics.worldbank.org/world-developmentindicators/, (last accessed 16 January 2020).

${ }^{76}$ Kempner and Loureiro (2002), p. 336.

${ }^{77}$ De Schutter (2009b), p. 19.
} 
food acquisition programme, known as Bolsa Familia, and the National School Feeding Programme, which effectively link family income and diets of poor people to small-scale agricultural production and family farming ${ }^{78}$. Bolsa Familia arranges cash transfers to poor families, which are linked to participation in specific health care programmes. The food acquisition programme guarantees that a proportion of the food procured for public schools, canteens, food baskets, etc. comes from family farmers. ${ }^{79}$ Similarly, the National School Feeding Programme guarantees free meals for schoolchildren partly sourced from family farming, drawing on a well-established family-farming certificate. ${ }^{80}$

These programmes were lauded for effectively supporting a dual farming system in which more diversified small-scale farming systems could co-exist alongside large-scale, agro-industrial systems. ${ }^{81}$ Though still in place, the programmes are under increasing pressure from Brazil's current government who is continuously cutting their funds. The government's publicly declared objective is neither to protect the natural environment in the Amazon and Cerrado nor to protect local communities, ${ }^{82}$ but rather to promote the expansion of large-scale agroindustrial production and extraction. Overall, power structures have shifted significantly and political support has weakened for the successful programmes outlined above. Effective protection of diversified farming systems appears elusive in Brazil's current political climate. Against this backdrop, the question arises as to whether Brazil's existing, but threatened, framework to promote family farming should have served as an entry point for stronger negotiation of sustainability-related trade concessions with Brazil during EU/EFTA-Mercosur talks.

Similar patterns can be observed in Argentina. There are different laws and policies in place aimed at fostering more integrated, diversified ways of farming. These include the National Forest Law, concretised by provincial forest laws, the law on family agriculture, and policies to promote agroforestry-oriented ways of production where livestock farming and forest management are combined synergistically, known as "manejo de bosque con ganaderia interna" or MBGI. ${ }^{83}$ However, research in Argentina has shown that, in practice, pressures of agroindustrial expansion often trump implementation of more integrated policy frameworks. ${ }^{84}$

\subsection{Trade as a lever to promote sustainable development in Mercosur countries and Europe}

As these patterns suggest, enabling small-scale, diversified farming systems to co-exist alongside large-scale, specialised systems requires stronger protection for the former in such settings. Since protection of key (e.g. highly biodiverse) biomes and related human rights are increasingly considered vital matters of common concern ${ }^{85}$, international trade could and should be more deliberately shaped to avoid undesired dynamics like those noted above. Instead of merely opening up and liberalising markets in an undifferentiated manner as was criticised by Porto et al. (2019) in a critical response to the EU-Mercosur trade agreement ${ }^{86}$,

\footnotetext{
${ }^{78}$ For an analysis of the impact of the policies, see e.g. Inguaggiato (2014); De Schutter (2009b).

${ }^{79}$ Veiga Aranha (2010), p. 96.

${ }^{80}$ Sanches Peraci and Alceu Bittencourt (2010), p. $193 \mathrm{ff}$.

${ }^{81}$ De Schutter (2009b).

${ }^{82}$ Diele-Viegas and Rocha (2020).

${ }^{83}$ See Ley 26.331 de Presupuestos Minimos de Proteccion Ambiental de los Bosques Nativos; Ley 27.118 de Agricultura Familiar, https://www.agro.unlp.edu.ar/novedad/argentina-tiene-una-ley-de-agricultura-familiar; and the Plan Nacional de Manejo de Bosques con Ganadería Integrada (PNMBGI), https://www.argentina.gob.ar/ambiente/tierra/bosques-suelos/manejo-sustentable-bosques/ganaderia-integrada.

${ }^{84}$ The EU funded Include Project assesses the impacts of these policies: https://includeproject.wordpress.com/; see e.g. Inguaggiato (forthcoming).

${ }^{85}$ For the emerging concept of common concern, see e.g. Cottier, Aerni, Karapinar, Matteotti, de Sépibus, Shingal (2014).

${ }^{86}$ Porto, Cintrão, Maluf (2019).
} 
In the EU/EFTA-Mercosur negotiations, for instance, part of the conceded tariff rate quota for Brazil could have been reserved for soy, meat, and other agricultural products stemming explicitly from family-farming. These could have been combined with additional sustainabilityoriented criteria. The reserved proportion of the tariff rate quota could have been increased over the years in order to incentivise expansion of more sustainable systems. Another option could have been to reserve a ratio of the conceded quota for products stemming from regions where - here in the case of Argentina - the forest law and MBGI policies are properly complied with, and/or where land tenure is effectively secured in line with the FAO Guidelines on Land Tenure. ${ }^{87}$ A variety of tariff differentiations are conceivable in support of diversified, sustainable farming systems. Institutional frameworks to ensure sound implementation would need to be developed.

Such incentives would have to be combined with market concessions for processed products stemming from the promoted farming systems. ${ }^{88}$ Enabling trade of value-added sustainable agricultural products would not only serve greater North-South equity, but also follow the recommendation by experts to transition towards farming systems that operate on the basis of closed nutrient cycles. Notably, this would also require more willingness in European countries to shift towards closed nutrient cycles in their own domestic farming systems and - as a consequence - to shift towards less intensive-livestock production, for example. Finally, European countries would need to reduce or dismantle certain policy mechanisms that serve to protect their domestic food-processing industry. ${ }^{89}$

Of course, it cannot be assumed that Mercosur countries would easily agree to such proposals, even if embedded in explicit reciprocal terms. If such trade incentives, however, were combined with effective financial support and reliable prospects of increased access to European markets for high quality value-added products, the picture might look different.

\section{Conclusion}

Given the persistence of severe sustainability problems in food production worldwide -as illustrated by the Brazilian example - states should seize the opportunity offered by trade agreements to foster more sustainable farming systems. They can do so by incorporating innovative trade rules along the lines of carefully designed, non-discriminatory PPMs that comply with fundamental principles of international law, in combination with provision of technical and financial support. Trade partners should strive to overcome their reluctance towards PPMs, recognising the reciprocal benefits they can provide. The EFTA-Indonesian Comprehensive Economic Partnership Agreement (CEPA) could serve as a good example going forward, provided its implementation is consistent with the text of the agreement. Nevertheless, the approach chosen in the CEPA has limitations. Merely market concessions for palm oil were made contingent on compliance with sustainability criteria, rather narrowly focusing on challenges related to palm oil production in Indonesia. A variety of other - likely acute - environmental and social problems of food production in EFTA countries were not considered in the negotiations. The chosen approach would gain recognition if the trade agreement was used as a lever to promote sustainable transformation of farming systems in all the partner countries involved.

In order to increase the sustainability impacts of this and other such agreements, effective market concessions are needed that cover not just a few, but rather a range of agricultural

\footnotetext{
${ }^{87}$ Food and Agriculture Organization (FAO) (2012).

${ }^{88}$ While, from a sustainability perspective, farming systems of closed nutrient cycles are to be promoted, there is a complementary need for a trading system encouraging not so much commodity trade but rather trade in valueadded products. See e.g. a related World Bank report: Mattoo, Whang, Wei (2013).

${ }^{89}$ See Bürgi Bonanomi, Jacobi, Scharrer (2018), chapter 3.
} 
products - including high-value processed goods - stemming from diversified farming systems, especially for partner countries more in need of such concessions. Further, additional substantive provisions of the trade agreement - e.g. those concerning non-tariff barriers or the protection of intellectual property in seed production - would need to be shaped in view of the envisaged sustainability goals. In this way, the innovative approach presented and discussed in this paper is only part of a broader picture. It can and should be refined in future agreements to come.

\section{References}

Bartels L (2014). A model Human Rights clause for the EU's international trade agreements. German Institute for Human Rights and Misereor

Beckert B, Dittrich C, Adiwibowo S (2014) Contested land: An analysis of multi-layered conflicts in Jambi province, Sumatra, Indonesia. ASEAS - Austrian Journal of SouthEast Asian Studies 7(1):75-92

Bowman M S, Soares-Filho B S, Merry F D, Nepstad D C, Rodrigues H, Almeida O T (2012) Persistence of cattle ranching in the Brazilian Amazon: A spatial analysis of the rationale for beef production. Land Use Policy, 29:558-568

Bundesamt für Umwelt (2018) Umwelt-Fussabdrücke der Schweiz. Zeitlicher Verlauf 1996 2015. BAFU, Bern

Bürgi Bonanomi E (2011) Trade law and responsible investment. In: International Land Coalition (ILC), Oxfam, Somo, WTI, International instruments influencing the rights of people facing investment in agricultural lands, pp 68-88

Bürgi Bonanomi E (2015) Sustainable development in international law making and trade, international food governance and trade in agriculture. Edward Elgar Publishing, Cheltenham, chapter 7.3.3.

Bürgi Bonanomi E (2017) Measuring Human Rights impacts of trade agreements: Ideas for improving the methodology, comparing the EU's sustainability impact assessment practice and methodology with Human Rights impact assessment methodology. Journal of Human Rights in Practice (Oxford University Press) 9:481-503

Bürgi Bonanomi E (2019) Die Nachhaltigkeit im Handelsabkommen mit Indonesien, mit besonderem Fokus auf die Regulierung des Palmöl-Imports. Studie im Auftrag der Agrarallianz, CDE

Bürgi Bonanomi E, Jacobi J, Scharrer B (2018) Food sustainability in Bolivia through fair food in Switzerland? How to improve food sustainability in both the north and the south through sustainable trade relations. Latin American Journal of International Trade Law LATAM 6(2):27-65

Celentano, D, Rousseau G X, Muniz F H, van Deursen Varga I, Martinez C, Carneiro M S, Miranda M V C, Barros M N R, Freitas L, da Silva Narvaes I, Adami M, Rodrigues Gomes A, Rodrigues J C, Martins M B (2017) Towards zero deforestation and forest restoration in the Amazon region of Maranhão state, Brazil. Land Use Policy 68:692-698. https://doi.org/10.1016/j.landusepol.2017.07.041

Chappell M J, LaValle L A (2011) Food security and biodiversity: can we have both? An agroecological analysis. Agriculture and Human Values, 28:3-26. https://doi.org/10.1007/s10460-009-9251-4

Colchester M, Chao S (eds) (2013) Conflict or Consent? The oil palm sector at a crossroads. FPP, Sawit Watch, Tuk Indonesia 
Cottier T (2015) Renewable energy and process and production methods (E15Initiative). International Centre for Trade and Sustainable Development (ICTSD) and World Economic Forum, Geneva

Cottier T (2018) The implications of EC - Seal products for the protection of core labour standards in WTO law. In: Gött H (eds) Labour standards in international economic law. Springer International Publishing, pp. 69-92

Cottier T, Oesch M (2005) International trade regulation. Staempfli, Bern, London

Cottier T, Nortova O, Shingal A (2014) The potential of tariff policy for climate change mitigation: Legal and Economic Analysis. Journal of World Trade 48(5):1007-1037

Cottier T, Aerni P, Karapinar K, Matteotti S, de Sépibus J, Shingal. A (2014) The principle of common concern and climate change. Archiv des Völkerrechts 52(3):293-325

De Schutter O (2009a) Report of the special rapporteur on the right to food. Mission to the World Trade Organization, A/HRC/10/5/Add.2.

De Schutter O (2009b) Mission to Brazil. Report of the special rapporteur on the right to food. A/HRC/13/33/Add.6.

De Schutter O (2015). Trade in the service of sustainable development. Linking trade to labour rights and environmental standards. Hart Publishing, Oxford and Portland

Dommen C (2020) Blueprint for a Human Rights impact assessment of the planned comprehensive free trade agreement between EFTA and Mercosur. Study commissioned by alliance sud

Diele-Viegas L M, Rocha C F D (2020) Why releasing mining on Amazonian indigenous lands and the advance of agrobusiness is extremely harmful for the mitigation of world's climate change? Comment on Pereira et al. (Environmental Science \& Policy 100 (2019) 8-12). Environmental Science \& Policy 103:30-31

Escobar H (2019) Amazon fires clearly linked to deforestation, scientists say. Science, 365(6456):853. doi:10.1126/science.365.6456.853

European Free Trade Association Secretariat (EFTA) (2019) EFTA-Mercosur free trade negotiation - Conclusion in substance of the EFTA-Mercosur free trade negotiations, 23 August 2019

European Union (EU) (2019) New EU-Mercosur trade agreement, The agreement in principle. 1st July 2019, Brussels, pp. 1-17

Eyhorn F, Muller A, Reganold J P, Frison E, Herren H R, Luttikholt L, Mueller A, Sanders J, Scialabba N EH, Seufert V, Smith P (2019) Sustainability in global agriculture driven by organic farming. Nature Sustainability 2:253-255

FAOSTAT (access to food and agriculture data of the Food and Agriculture Organization of the United Nations (FAO)) (2020) Data for the year 2017. http://www.fao.org/faostat/en/\#data, (last accessed 15 January 2020)

Food and Agriculture Organization of the United Nations (FAO) (2012) Voluntary guidelines on the responsible governance of tenure of land, fisheries and forests in the context of national food security. http://www.fao.org/3/a-i2801e.pdf

Food and Agriculture Organization of the United Nations (FAO), Institut national de la recherche agronomique (INRA) (2016). Innovative markets for sustainable agriculture. How innovations in market institutions encourage sustainable agriculture in developing countries, by Loconto A, Poisot A S, Santacoloma P (eds). Rome, Italy 
Góes C, Karpowicz I (2017) Inequality in Brazil: A regional perspective. International Monetary Fund

Graesser J, Ramankutty N, Coomes O T (2018) Increasing expansion of large-scale crop production onto deforested land in sub-Andean South America. Environmental Research Letters, 13(8):084021. doi:10.1088/1748-9326/aad5bf.

Graeub B E, Jahi Chappell M, Wittman H, Ledermann S, Bezner Kerr R, Gemmill-Herren B (2016) The state of family farms in the world. World Development 87:1-15

High Level Panel of Experts (HLPE) (2019) Agroecological and other innovative approaches for sustainable agriculture and food systems that enhance food security and nutrition. A report by the High Level Panel of Experts on Food Security and Nutrition of the Committee on World Food Security, Rome

Holzer K (2014) Carbon-related border adjustment and WTO law. Edward Elgar Publishing, Cheltenham

Howse R (2012) Regulatory measures. In: Daunton M, Narlikar A, Stern R M (eds) The Oxford Handbook on The World Trade Organization. Oxford University Press, Oxford

Independent Group of Scientists appointed by the Secretary-General (2019) The future is now - Science for achieving sustainable development, Global Sustainable Development Report (GSDR), United Nations, New York

Inguaggiato C (2014) Agrarian reform, social movements and community based organization: The emergence of new organizational forms? A case study in Northeast Brazil. PhD dissertation. University of Trento

Inguaggiato C (forthcoming) Governance structures and competing forest policy preferences: a policy network study of forest law in Northwest of Argentina

International Social Science Council (ISSC), Institute of Development Studies (IDS), United Nations Educational, Scientific and Cultural Organization (UNESCO) (2016) World Social Science Report 2016. Challenging inequalities: Pathways to a just world. UNESCO Publishing, Paris

IPES-Food (2016) From uniformity to diversity: a paradigm shift from industrial agriculture to diversified agroecological systems. International Panel of Experts on Sustainable Food systems

Kempner K, Loureiro A (2002) The global politics of education: Brazil and the World Bank. Higher Education 43:331-354

Kiriti Nganga T, Mugo M G, Bürgi E, Kiteme B (2018) Impact of economic regimes on food systems in Kenya. R4D Food Sustainability. Working Paper No. 7

Kremen C, Iles A, Bacon C (2012) Diversified farming systems: An agroecological, systemsbased alternative to modern industrial agriculture. Ecology and Society 17(4) 44:1-19

Manoli G, Meijide A, Huth N, Knohl A, Kosugi Y, Burlando P, Ghazoul J, Fatichi S (2018) Ecohydrological changes after tropical forest conversion to oil palm. Environmental Research Letters 13:064035

Mattoo A, Whang Z, Wei SJ (eds) (2013) Trade in value added, developing new measures of cross-border trade. The International Bank for Reconstruction and Development/The World Bank.

McCarthy J F (2010) Processes of inclusion and adverse incorporation: oil palm and agrarian change in Sumatra. Indonesia. Journal of Peasant Studies 37(4):821-850 
Messerli P, Giger M, Dwyer MB, Breu T, Eckert S (2014) The geography of large-scale land acquisitions: Analysing socio-ecological patterns of target contexts in the global South. Applied Geography 53:449-459

Moffette F, Gibbs H (2018) Agricultural displacement and deforestation leakage in the Brazilian legal Amazon. Retrieved from Semantic Scholar, 16 January 2020

Murray Li T (2014) The gendered dynamics of Indonesia's oil palm labour regime. Asia Research Institute, Working Paper No. 225

Murray Li T (2017a) The Price of un/freedom: Indonesia's colonial and contemporary plantation labor regimes. Comparative Studies in Society and History 59(2):245-276

Murray Li T (2017b) Intergenerational displacement in Indonesia's oil palm plantation zone. The Journal of Peasant Studies, 44:6

Musselli I (2017). Agriculture, price stabilisation and trade rules: A principled approach. Brill Nijhoff, Leiden

Oberlack C, Sietz D, Bürgi Bonanomi E, de Brémond A, Dell'Angelo J, Eisenack K, Ellis E C, Epstein G, Giger M, Heinimann A, Kimmich C, Kok M TJ, Manuel-Navarrete D, Messerli P, Meyfroidt P, Václavík T, Villamayor-Tomas S (2019) Archetype analysis in sustainability research: meanings, motivations, and evidence-based policy making. Ecology and Society 24(2):26

Ostrom E (2005) Understanding institutional diversity. Princeton University Press, Princeton, New Jersey, USA

Porto S, Cintrão R P, Maluf, R (2019) Trade agreement between European Union and the Mercosur: some critical points on agrifood matters. https://www.cde.unibe.ch/e65013/e542846/e542016/e837263/e837264/AgreementEUMercosur_eng.pdf

Ricciardi V, Ramankutty N, Mehrabi Z, Jarvis L, Chookolingo B (2018) How much of the world's food do smallholders produce?. Global Food Security 17:64-72

Rist S, Bürgi Bonanomi E, Giger M, Hett C, Scharrer B, Jacobi J, Lannen A (2020) Variety is the source of life: Agrobiodiversity benefits, challenges, and needs. Swiss Academies Factsheet 15(1). Swiss Academies of Arts and Sciences. Bern, Switzerland

Sanches Peraci A, Alceu Bittencourt G (2010). Family farming and price guarantee programs in Brazil: The food acquisition program (PAA). In: da Silva J G, del Grossi M, de França C G (eds) The Fome Zero (Zero Hunger) Program: The Brazilian Experience

Solar J, Bürgi Bonanomi E (forthcoming, 2021) PPMs in European trade practice, comparative legal analysis

Swiss Federal Council (2017) Auswirkungen von Freihandelsabkommen, Bericht der GPK-N vom 4. Juli 2017, Stellungnahme des Bundesrates vom 22. September 2017

The World Bank (2020) World Development Indicators. http://datatopics.worldbank.org/world-development-indicators/, (last accessed 16 January 2020)

Tschopp M, Bieri S, Rist S (2018) Quinoa and production rules: How are cooperatives contributing to governance of natural resources?. International Journal of the Commons 12(1):402-427 
United Nations Conference on Trade and Development (UNCTAD) (2013) Trade and Environment Review 2013 - Wake up before it is too late: Make agriculture truly sustainable now for food security in a changing climate

Veiga Aranha A (2010) Zero hunger: A project turned into a government strategy. In: da Silva J G, del Grossi M, de França C G (eds) The Fome Zero (Zero Hunger) Program: The Brazilian Experience

Vonplon D (2019) Freihandel und Nachhaltigkeit passen zusammen. Neue Zürcher Zeitung NZZ, 17. Oktober 2019

Znoj H (2016) Korruption im und um das indonesische Verteidigungsministerium. Expertise. Institut für Sozialanthropologie, Universität Bern 